\title{
O FORO POR PRERROGATIVA NO SUPREMO TRIBUNAL FEDERAL: AS RAZÕES DE UMA “CIRANDA" JURISPRUDENCIAL
}

\author{
THE FORUM BY PREROGATIVE IN THE BRAZILIAN SUPREME COURT: THE
} REASONS FOR A “CIRANDA” JURISPRUDENTIAL

\author{
João Roberto Silva Ataíde ${ }^{1}$ \\ Ilton Norberto Robl Filho ${ }^{2}$
}

\begin{abstract}
RESUMO: Considerado um apanágio a proteger o exercício das funções públicas de demandas frívolas e perseguições políticas, as regras do foro por prerrogativa tem passado por constantes alterações através da jurisprudência do Supremo Tribunal Federal. Desde a promulgação da Constituição de 1988, o Tribunal tem modificado a compreensão e o assentamento de regras processuais do instituto, ainda que o cenário apontasse para uma escassa, e praticamente imutável, previsão normativa sobre o assunto. A pesquisa, então, denomina esse fenômeno de intensa mutação de jurisprudência sobre o foro por prerrogativa de "ciranda" jurisprudencial. Dessa forma, o escrito busca investigar as razões dessa ciranda interpretativa através da análise de decisões que representaram quebras de paradigmas sobre o foro por prerrogativa. Essas decisões vão desde o julgamento, em 1999, do Inquérito n. ${ }^{\circ}$ 687-SP, que rompeu com centenária jurisprudência sobre o assunto, até o ano de 2018, na maior alteração já realizada sobre o instituto no julgamento da Ação Penal n. ${ }^{\circ}$ 937-RJ. Através da análise dos votos dos Ministros, são perceptíveis elementos como o individualismo dos julgadores, a estrutura deliberativa do Tribunal, a força da opinião pública e o cenário político nos votos do Colegiado. Neste sentido, o artigo dedicou-se a avaliar como esses fatores internos e externos ao Tribunal influenciaram nas tomadas de decisão dos membros da Corte sobre o tema.
\end{abstract}

\footnotetext{
${ }^{1}$ Mestre em Direito Constitucional pelo Instituto Brasileiro de Ensino, Desenvolvimento e Pesquisa - IDP (2021). Pós-graduado em Direito Constitucional Aplicado pela Faculdade Damásio de Jesus (2014). Graduado em Direito pela Universidade de Rio Verde - UniRV (2006). Professor Substituto na Universidade Federal de Goiás - UFG (2016-2017). Professor de Direito Constitucional e Direito Administrativo. Advogado inscrito na Ordem dos Advogados do Brasil - OAB, Seccional de Goiás. Contato: joaorobertoataide@gmail.com. Lattes: http://lattes.cnpq.br/8993440310308354. ORCID: https://orcid.org/0000-0002-2827-4834.

${ }^{2}$ Doutor (2012) e Mestre (2008) em Direito pela Universidade Federal do Paraná (UFPR). Realizou Pós-Doutorado ( $1^{\circ}$ Semestre de 2015) em Direito Constitucional no Programa de Pós-Graduação em Direito da Pontifícia Universidade Católica do Rio Grande do Sul (PUCRS). Pesquisador Visitante na Faculdade de Direito da Universidade de Toronto - Canadá (2012) e do Max Planck em Heidelberg - Alemanha (2013). Professor Adjunto da Faculdade de Direito da UFPR e do Instituto Brasileiro de Ensino, Desenvolvimento e Pesquisa - IDP. Diretor da Academia Brasileira de Direito Constitucional (ABDConst). Lattes: http://lattes.cnpq.br/6850075090457033.
} 
Palavras-chave: Jurisdição constitucional. Foro por prerrogativa. Supremo Tribunal Federal. Mutação. Política.

ABSTRACT: Considered an attribute to protect the exercise of public functions from frivolous demands and political persecution, the rules of the forum by prerogative have undergone constant changes through the jurisprudence of the Brazilian Supreme Court. Since 1988 when the promulgation of the Constitution, the Court has modified the understanding and establishment of procedural rules of the institute, even though the scenario pointed to a scarce, and practically immutable, normative provision on the subject. The research, then, calls this phenomenon of intense mutation of jurisprudence on the forum by the prerogative of "ciranda" jurisprudence. Thus, the article seeks to investigate the reasons for this interpretative circle through the analysis of decisions that represented paradigm shifts about the forum by prerogative. These decisions range from the 1999 judgment of Inquiry n. $687-$ SP, which broke with centuries-old jurisprudence on the subject, until 2018, in the biggest change ever made to the institute in the judgment of Criminal Action n. 937-RJ. Through the analysis of the Ministers' votes, elements such as the individualism of the judges, the deliberative structure of the Court, the strength of public opinion and the political scenario in the votes of the Collegiate can be perceived. In this regard, the article was devoted to evaluating how these factors, both internal and external to the Court, influenced the decisionmaking of the members of the Court on the subject.

Keywords: Judicial review. Forum prerogative. Brazilian Supreme Court. Mutation. Politics.

Sumário: 1. Introdução; 2. O foro por prerrogativa no Supremo Tribunal Federal: uma "ciranda jurisprudencial; 3. Das decisões sobre o foro por prerrogativa: o que move a jurisprudência do Supremo Tribunal Federal?; 3.1. A política no Supremo Tribunal Federal; 3.2. Da opinião pública como fator decisório; 3.3. O temor pela prescrição como fator decisório. 4. Considerações finais; 5. Referências bibliográficas.

\section{INTRODUÇÃO}

Conforme a perspectiva tradicional, a competência por prerrogativa de função, ou simplesmente foro por prerrogativa, em sua particularidade, ocasiona o início de uma ação penal se dê imediatamente em um colegiado. Em outras termos, essa prerrogativa faz com que a ação seja proposta diretamente em órgão de segunda ou instância superior, que, por sua vez, executará as funções de investigação, instrução e julgamento do processo, como se juízo da primeira instância fosse. (MARCHIONATTI, 2019, p. 1)

Considerando essa dinâmica, Fernando da Costa Tourinho Filho aduz que o foro por prerrogativa se constitui como apanágio que determinadas pessoas detêm de serem processadas e julgadas diretamente nos Tribunais, por exercerem relevantes funções no 
cenário jurídico político (TOURINHO FILHO, 2012). O objetivo do instituto, de natureza predominantemente constitucional e política, é permitir que determinadas autoridades desempenhem suas funções com autonomia e independência, cujos atos, caso questionados, dever-se-ão ser julgados com imparcialidade por um colegiado forte e imune a pressões externas. (STF, ADI 2.587)

O foro por prerrogativa sempre existiu na história do constitucionalismo brasileiro, estando presente em todas as versões das Cartas Magnas pátrias, fossem as imperiais, republicanas ou ditatoriais. E em todas essas Cartas, atribuiu-se à mais alta Corte do Judiciário a competência para julgar as máximas autoridades do país, função que no atual regime Constitucional é exercido pelo Supremo Tribunal Federal.

Apesar de sempre presente em todos os textos constitucionais pátrios, é possível notar que a Carta Magna, costumeiramente, se limitou em enumerar o rol de autoridades com direito a foro por prerrogativa, não especificando de que forma essas regras seriam aplicadas. Essas regras, ao longo dos anos, foram definidas pela jurisprudência do STF que, em considerável número de oportunidades, especialmente na vigência da atual Constituição, as modificou. E essa constante mutação de entendimento e aplicação de regras sobre o foro por prerrogativa recebeu, por parte da pesquisa, a denominação de "ciranda jurisprudencial".

As consequências dessas constantes alterações, que ocorreram sob as mais diversas argumentações, não tem sido exatamente benéficas, tendo em vista um quadro de insegurança jurídica provocado pelos contraditórios conteúdo das decisões, além da inconstância jurisprudencial sobre o tema. Em um cenário de escassa previsão normativa sobre o instituto, bem como a ausência de alterações das normas, quais foram os argumentos, fundamentos e critérios tem sido usado pelos Ministros para estender ou restringir o foro por prerrogativa? As decisões tomadas estão consoantes à essência do foro por prerrogativa? Há fatores explicativos da variação na definição dos marcos referenciais?

Sem a pretensão de esgotar todos os fenômenos aptos a responder as perguntas então formuladas, o presente artigo analisará, sob o prisma da Constituição Federal de 1988, os leading cases sobre o tema, assim considerados os casos decididos pelo Supremo que representaram mudanças de paradigmas na compreensão e aplicação do foro por prerrogativa no Tribunal. Nas razões apresentadas pelos Ministros através dos votos, buscar-se-á 
desenvolver as principais as motivações de tantas mudanças jurisprudenciais sobre o foro por prerrogativa, com destaque para os fatores (i) política, (ii) opinião pública e (iii) prescrição.

Nesse sentido, a investigação sobre os fatores que move, a ciranda jurisprudencial do foro por prerrogativa, permitirá ao leitor perceber como a mais alta Corte do Judiciário brasileiro lida com os mais diversos fatores, endógenos ou exógenos, aptos a influenciar em suas decisões.

\section{O FORO POR PRERROGATIVA NO SUPREMO TRIBUNAL FEDERAL: UMA "CIRANDA JURISPRUDENCIAL"}

Em 2008, em entrevista ao sítio eletrônico do Supremo Tribunal Federal, o Ministro Gilmar Mendes denominou de "ciranda de processos" o movimento que as ações penais contra autoridades talhavam pelas diversas instâncias judiciais. Esse fenômeno ocorria por conta das frequentes mudanças de cargo público dos acusados que, por sua vez, provocavam alteração de competência. Esse movimento, então, era tido como o responsável por acarretar uma demora no julgamento das ações decorrentes do foro por prerrogativa, cuja resolução poderia ocorrer, segundo o Ministro, por uma revisão na jurisprudência do Supremo. (STF, 2008)

Mais que uma simples entrevista, as palavras do então Presidente do STF revelavam o modus operandi da mais alta Corte do Judiciário nacional quando deparada com as disfuncionalidades do foro por prerrogativa no Tribunal: o de que aqueles problemas poderiam ser combatidos via mudança de jurisprudência, tendo em vista a escassez de normas sobre a temática, e a indisposição do Legislativo para cria-las. Nesse sentido, como as questões controvertidas sobre o foro penal originário eram rotineiras na pauta do Tribunal, o Supremo era constantemente obrigado a alterar sua jurisprudência a corrigir e adequar sua prestação jurisdicional. Por essa razão, as muitas modificações da interpretação sobre o foro por prerrogativa na jurisprudência do STF, inspirada na expressão do Min. Gilmar Mendes, é denominada neste escrito de "ciranda jurisprudencial".

$\mathrm{Na}$ vigência da atual Constituição, essa ciranda tem seu marco inicial quando do julgamento de Questão de Ordem no Inquérito nº 687-DF, ocorrido em 1999. Até então, 
prevalecia o sesquicentenário entendimento insculpido através da Súmula no 394 , criada em 1964. Seu texto consagrava o entendimento de que cometido o crime durante o exercício do cargo, prevaleceria as regras da competência por prerrogativa de função, ainda que o inquérito ou a ação penal fossem iniciados após a sua cessação (CANOTILHO, 2018, p. 1.471). Era o que se denominava, pela doutrina, de perpetuatio jurisdictionis. (SANTOS, 1985, p. 269)

Todavia, sob argumentos como o princípio republicano da igualdade, elevado número de ações penais na Corte, e ausência do conteúdo da Súmula n. ${ }^{o} 394$ na Carta de 1988, o Plenário do STF cancelou o verbete no julgamento em questão. Dessa forma, o fim do exercício do cargo ou função pública também acarretaria no fỉm competência do Supremo para julgar o caso, independentemente da natureza e do momento da prática do delito. (MARCHIONATTI, 2019, p. 71-72).

Em 2002, novamente a temática foro por prerrogativa voltou ao Supremo, dessa vez através das ADI's n. ${ }^{\circ} 2.797 / \mathrm{DF}$ e n. ${ }^{\circ} 2.860 / \mathrm{DF}$, que contestavam a constitucionalidade da Lei 10.628/2002. Essa lei, que reintroduzira a perpetuatio jurisdictionis aos ex-detentores de cargos públicos, foi qualificada pela Corte como "clara e evidente reação legislativa ao cancelamento da Súmula n. 394”. Desse modo, o STF julgou a lei inconstitucional, afirmando que a legislação ordinária não poderia impor uma última e determinada interpretação da Constituição, missão essa precípua do Tribunal. E, novamente, o Supremo pôs fim ao foro por prerrogativa aos ex-detentores de cargos públicos.

Já em março de 2006, o Supremo, no julgamento de Q.O. no Inquérito n. ${ }^{\circ}$ 2.245-MG, que posteriormente deu origem à Ação Penal n..$^{\circ}$ 470, modificou a aplicação das regras do foro por prerrogativa ao ampliar seu o alcance a pessoas que não o possuíam. No caso em questão, considerando que apenas seis dos quarenta acusados detinham a prerrogativa de serem julgados pelo STF, a Corte, alterando sua jurisprudência até então dominante (STF, HC n. ${ }^{\circ}$ 73.423-RJ), afastou a possibilidade do desmembramento do caso, e se considerou competente a julgar todos os acusados. O receio de decisões conflitantes na primeira e segunda instância, e dessas instâncias em relação ao STF sobre o mesmo caso, compôs a argumentação da tese vencedora.

Chegado o final dos anos 2000, a ciranda jurisprudencial no Supremo continuou a se 
movimentar quando o Tribunal tratou, de maneira diversa, dois casos de circunstâncias praticamente idênticas. Na Q.O. da Ação Penal n. ${ }^{\circ} 333-P B$, julgada em 2007, a renúncia do acusado ao cargo de Deputado Federal, em momento próximo ao julgamento, resultou no fim da competência da Corte. Para os Ministros, a renúncia se mostrava como ato legítimo e, não mais ostentando o acusado da condição de parlamentar, não havia outra saída senão a remessa dos autos à instância inicial. Todavia, apenas três anos depois, quando do

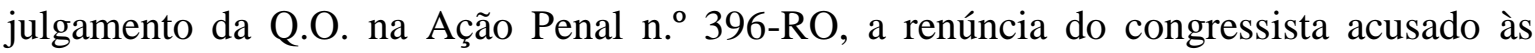
vésperas do julgamento foi considerada como fraude processual, tendo em vista a proximidade de ocorrência de prescrição punitiva. O STF, então, pugnou pela a ineficácia da abdicação do cargo, e mantendo sua competência, julgou e condenou o acusado.

No mesmo ano de 2010, em Questão de Ordem no julgamento da Ação Penal nº 536MG, o Supremo retomou o entendimento firmado na A.P. no 333-PB, afirmando que a renúncia do acusado cessaria o mandato e, consequentemente, a competência penal da Corte. Neste julgamento, tentou-se fixar um momento em que a renúncia do acusado não mais surtisse efeitos quanto à mudança de competência, a se evitar a tão criticada "ciranda de processos". Todavia, como não houve consenso sobre o momento ideal, a questão continuou indefinida, continuando Ministros e Turmas julgando a questão de modos diversos.

E em 2018, quando do julgamento da Ação Penal n 937/RJ, o Supremo Tribunal Federal, mais uma vez, promoveu uma sensível modificação na aplicação do foro por prerrogativa. Sob argumentos de excesso de processos e autoridades sob sua jurisdição, além do não exercício de sua vocação de guardião da Constituição, o Supremo decidiu que sua competência se limitaria a crimes praticados no período do exercício do cargo e em razão do seu ofício. Já os delitos sem relação, ou praticados fora do período de exercício de cargo público, a competência caberia agora às Instâncias iniciais. Ademais, definiu-se que a perpetuação da jurisdição do STF nas ações penais dar-se-ia com a publicação de intimação para apresentação de alegações finais.

Todavia, ainda que o Plenário houvesse decidido que caberia às instâncias iniciais para processamento de crimes sem conexão com o exercício do cargo público, o Tribunal, em 2019, quando do julgamento da Reclamação $n^{\circ}$ 25.537-DF, mostrou que essa competência não seria plena. Para a maioria dos Ministros, atos instrutórios como busca e 
apreensões realizadas nos locais de serviço dos acusados, demandariam de consentimento do Supremo para que tivessem validade, sob pena de usurpação de competência da Corte. Dessa forma, é possível aferir que a decisão na A.P. no 937/RJ, a qual atribuía a competência à instância inicial para apreciar crimes estranhos ao cargo desempenhado por autoridades, já havia sido alterada de alguma forma.

As modificações de entendimento expostas acima mostram, ainda que superficialmente, a dinâmica da ciranda jurisprudencial do foro por prerrogativa no STF, que nas últimas duas décadas foi modificado em mais de uma dezena de vezes pela Corte. Não se conhece tema ou instituto, no direito brasileiro, que tenha passado por tantas alterações e complementações nesse período. Assim sendo, o que explicaria tal movimento?

\section{DAS DECISÕES SOBRE O FORO POR PRERROGATIVA: O QUE MOVE A JURISPRUDÊNCIA DO SUPREMO TRIBUNAL FEDERAL?}

Entender como o Supremo formula suas decisões diante de fatores jurídicos e não jurídicos é essencial para a devida compreensão da ciranda jurisprudencial quanto ao foro por prerrogativa. Frente a um cenário de inexistência de regras específicas sobre o instituto, é válido investigar e apontar aqueles que seriam os principais propulsores da constante mutabilidade quanto à interpretação das regras do foro por prerrogativa. No presente artigo, elegeu-se aqueles que seriam os três principais, sendo eles a política, a opinião publica e a prescrição, aos quais será realizada breve análise quanto à inflência desses elementos nas motivações das decisões da Corte.

\subsection{A POLÍTICA NO SUPREMO TRIBUNAL FEDERAL}

O termo "política" foi cunhado, inicialmente e com maior notabilidade, por Aristóteles há cerca de dois mil e trezentos anos, o qual veio a defini-la como as ações de todos os homens praticadas dentro da pólis visando seu bem estar, seja ele individual ou coletivo. Esse bem geral deveria ser garantido por um Governo, que exerceria o poder supremo do Estado, guiado por uma Constituição deliberada em assembleia geral pelos cidadãos, cuja função estaria na distribuição dos poderes, na definição da forma de Governo e garantia do fim maior da sociedade civil. (ARISTÓTELES, 2006, p. 27) 
Já na era moderna, o termo política teve seu significado original alterado, passando a representar a atividade que tem como referência a "pólis" (ou simplesmente o Estado), sendo nominada como "doutrina do Estado", "ciência política ou "filosofia política" (BOBBIO, 1998, p. 954). Conquanto, apesar da nomenclatura utilizada, ao presente escrito interessa a discussão sobre o primado da Constituição e sua relação com a política e o Estado, a qual desenvolveu-se com maior intensidade ao fim do século XVIII. (BERCOVICI, 2004, p. 5)

No Estado brasileiro, a Carta Magna de 1988 conferiu ao STF um amplo poder de imprimir a última palavra sobre temas constitucionais no sistema político, sendo expressamente denominado de guardião da Constituição Federal. Todavia, a amplitude do texto constitucional fez com que praticamente todas as matérias, inclusive as de cunho político, fossem inseridas em seu escrito, reduzindo assim o campo de liberdade de administradores e legisladores. Dessa forma, qualquer movimento mais brusco dessas autoridades, poder-se-ia levantar dúvidas sobre sua constitucionalidade e, portanto, levar o Supremo a se pronunciar. (VIEIRA, 2008, p. 447)

Por essas razões, ainda que haja alguma controvérsia, admite-se que o Supremo Tribunal Federal é um Tribunal político por participar cada vez mais da gestão do país, nos moldes do conceito aristotélico de política como o de "administração da "pólis"”. (FALCÃO, 2015, p. 92). A atuação da Corte nessa gestão do Estado se daria através da atividade jurisdicional, julgando os casos de acordo com disposto no texto constitucional, com possibilidade de auxílio das leis ordinárias e da jurisprudência, com independência e poderes também garantidos pela Constituição.

Contudo, em processos onde há o envolvimento de altas autoridades públicas, ou relevantes atores políticos, o Tribunal pode ter sua independência e autoridade testadas (LUNARDI, 2020, p. 125). Esses testes podem se dar tanto na possibilidade de proferir decisões contrárias a grandes interesses, como na coerência dessas decisões quando houver pluralidade de casos a julgar.

Nesse contexto, há decisões sobre o foro por prerrogativa que chamam a atenção pela similaridade de circunstâncias fáticas, mas que receberam do Tribunal Constitucional decisões diversas, sem que houvesse justificativa expressa para isso. Dando azo à ciranda 
jurisprudencial sobre o foro por prerrogativa, iniciar-se-á pela análise do conteúdo das decisões na ADI no 3.289-DF, e ADI nº 2.797-DF/ADI n 2.860-DF.

Julgada em 05.05.2005, a ADI no 3.289-DF tinha como objeto de análise uma possível inconstitucionalidade da Lei n. ${ }^{\circ}$ 11.036/04, que conferia ao Presidente do Banco Central do Brasil a equiparação como Ministro de Estado. Como consequência, o cargo conferiria ao seu ocupante as prerrogativas inerentes à função, como o foro penal originário no Supremo Tribunal Federal. O apanágio, todavia, por força do art. $2^{\circ}$, parágrafo único da lei ora contestada, se estenderia, também, aos ex-ocupantes do cargo, desde que se referisse a fatos praticados no exercício da função.

À época do julgamento, predominava na jurisprudência da Corte o seguimento em que o foro por prerrogativa não seria aplicável aos ex-detentores de cargo ou mandato público, por força do cancelamento da Súmula $n^{\circ} 394$, realizado no julgamento do Inquérito $\mathrm{n}^{\circ}$ 687-SP. Todavia, o Supremo Tribunal Federal afirmou a constitucionalidade da Lei $\mathrm{n}^{\circ}$ 11.036/04, garantindo o foro por prerrogativa aos atuais e aos ex-ocupantes do cargo de Presidente do Banco Central.

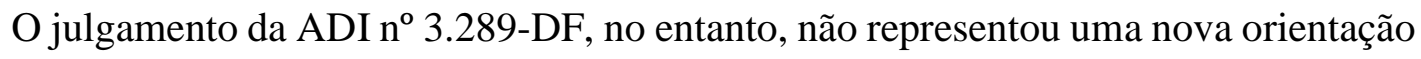
sobre o foro por prerrogativa, ou um resgate de uma jurisprudência da Corte sepultada com o cancelamento da Súmula n. ${ }^{\circ}$ 394. Na verdade, tratava-se de mais um capítulo da ciranda jurisprudencial do instituto. Essa constatação deriva do fato de que, apenas quatro meses depois, em circunstâncias fáticas semelhantes, o Tribunal Constitucional, novamente, alterou seu entendimento.

O caso em questão tratou da ADI n ${ }^{\circ}$ 2.797-DF, julgada em 15.09.2005, versava sobre possível inconstitucionalidade da Lei 10.628/02, a qual reestabelecia a competência penal originária do STF aos ex-congressistas por atos praticados em razão do mandato. Essa competência, como dito anteriormente, havia sido extinta juntamente com a Súmula no 394 , por representar privilégios indevidos e ofensa a princípios republicanos, como a igualdade.

Porém, deixando de seguir o precedente da ADI n. ${ }^{\circ}$ 3.289-DF firmado meses antes, mais uma vez, o Supremo mudou sua posição a afirmar que a perpetuação da competência da Corte a ex-detentores de cargos públicos seria inconstitucional. O fundamento consistia ao fato que o legislador infraconstitucional não poderia impor interpretação autêntica da 
Constituição por lei ordinária por representar usurpação da competência do STF de interprete da Constituição. No caso, o cancelamento da Súmula n. 394 se mostrava como interpretação direta e exclusiva da Lei Fundamental, não podendo, então, ser modificado por ação do Congresso Nacional.

Todavia, em nenhum voto, seja na ADI n. ${ }^{\circ} 3.289-\mathrm{DF}$, seja na ADI n..$^{\circ}$ 2.797-DF, houve justificativa, fática ou legal, para o não cumprimento de precedente anterior, ainda que os casos fossem semelhantes. Desta forma, porque a interpretação sobre idêntica ou semelhante questão mudaram substancialmente? (CAMPOS, 2014, p. 296) Sem obter respostas nos votos dos Ministros que explicassem a disparidade de decisões, a única afirmação que se poderia fazer era a ocorrência do uso seletivo da subsunção, fenômeno caracterizado quando dois ou mais casos carregam profunda semelhança e possuem proximidade temporal, mas são decididos de formas distintas. (BENVINDO, 2007, p. 183)

A ausência de coerência no caso em questão representa em um primeiro momento, a violação aos precedentes, cujo respeito se mostra como forma de "preservar valores indispensáveis ao Estado de Direito, assim como de viabilizar um modo de viver em que o direito assume a sua devida dignidade”. Não obstante, os precedentes ainda tem o poder de "determinar condutas e gerar um modo de vida marcado pela responsabilidade pessoal". (MARINONI, 2019) Ademais, a quebra de coerência nas decisões pode por gerar forte impacto político, além da configuração de um possível uso político do Tribunal. (BENVINDO, 2007, p. 183)

Todavia, a ausência de coerência por parte do Tribunal também pode significar hipótese de um constitucionalismo seletivo, onde a interpretação constitucional e sua decisão é modificada conforme interesses ou importância do(s) ator(es) envolvido(s). A situação se mostra perigosa na medida em que a tradução da Carta Magna, através da jurisprudência, seja feita não com base em processo mental de elucidar um caso concreto, mas sim a dar roupagem constitucional à decisões políticas tomadas por bases e razões não jurídicas. (LUNARDI, 2020, p. 131) Não bastando, poder-se-ia estar diante de prática de um constitucionalismo abusivo (LANDAU, 2013, p. 195-196) pela falta de isonomia em casos que carregam profunda semelhança e proximidade temporal.

Porém, é necessário registrar que não se pode concluir que a simples ausência ou 
presença de coerência, bem como uso ou não de precedentes nas decisões do foro por prerrogativa, por parte do STF, possuem relação com a importância do cargo ou interesses políticos que possam estar em julgamento. Todavia, relevante se faz mostrar que, nos casos apresentados, não houve por parte da Corte uniformidade de tratamento á questões praticamente idênticas, cujas razões para a diferenciação não foram encontradas, ao menos expressamente, nos votos.

\subsection{DA OPINIÃO PÚBLICA COMO FATOR DECISÓRIO}

Não se olvida que umas das mais importantes funções da jurisdição constitucional é a interpretação da Constituição, capaz de estabelecer padrões decisórios sobre seu conteúdo a gerar segurança, previsibilidade e estabilidade nas relações jurídicas, econômicas e sociais. Leciona Konrad Hesse (2009, p. 134) que a interpretação ainda enfrenta o desafio de manter o texto Constitucional atualizado, tendo em vista as possibilidades de eventuais mudanças sociais, políticas e econômicas. Dessa forma, deve-se buscar uma interpretação da Constituição que lhe permota adaptar-se às novas condicionantes e situações.

Nesse mesmo sentido, Peter Häberle (2007, p. 214) ensina que "a jurisdição constitucional é variável, flexível, no tempo e no espaço", podendo "se converter em autoridade confirmadora da Constituição segundo a fase de desenvolvimento do concreto Estado constitucional que ela contribui a garantir". Dessa forma, admite-se que a interpretação de algum instituto pode ser modificada ou até mesmo afastada, face a ocorrência de mutações jurídicas ou alteração fáticas justificadoras de uma alteração. (ABBOUD, 2018, p. 523-524)

No caso das normas sobre o foro por prerrogativa, nota-se que desde a promulgação da Carta Republicana de 1988, não houve qualquer alteração quanto à sua previsão no texto Constitucional. Face a inércia do legislativo, coube ao Supremo Tribunal Federal a promoção das mudanças de aplicação das regras do foro por prerrogativa, criando-se, via jurisprudência, critérios de aplicação, de expansão ou retração de sua competência. Nesse quadro, então, pretende-se discutir acerca da suposta influência de um elemento capaz de conduz o Tribunal Constitucional a uma modificação em sua jurisprudência. Este elemento é a opinião pública, também chamada de vontade popular ou clamor público. (MELLO, 
2014, p. 361)

A opinião pública é entendida como um processo derivado de uma livre interação conversacional entre cidadãos no intuito de estabelecer um entendimento ou consenso sobre um tema. Todavia, para que essas opiniões se tornem públicas, é necessário um espaço onde ela se torne visível e possa se expandir o qual, atualmente, é encontrado na mídia, em especial pelo jornalismo (MARQUES, 2004, p. 72) em seus vários meios como televisão, rádio, impressos, internet e redes sociais.

Para a análise que comprovaria, ou não, a influência da opinião pública junto ao STF nos julgamentos que envolvem o foro por prerrogativa, selecionou-se a Q.O. no Inquérito n. ${ }^{\circ}$ 2.245-DF, julgado em 2006, que mais tarde originou a um dos emblemáticos casos já julgados pelo Supremo: a Ação Penal n. ${ }^{\circ}$ 470-DF. (MELLO, 2014) Em suma, prodecimento apurava um suposto esquema de corrupção que envolvia a compra de apoio político, em especial parlamentares da base governista, para respaldo dos projetos e planos do Governo Federal. Um dos meios de corrupção apurado era o pagamento mensal e em dinheiro a esses parlamentares, levando o caso a ser conhecido popularmente como "mensalão".

$\mathrm{Na}$ medida em que as investigações avançavam e grandes nomes da política se viam relacionados ao esquema de corrupção, a opinião pública e a mídia aumentavam a repercussão do caso. Não sendo o bastante, houve ainda forte pressão da imprensa nacional pela celeridade do julgamento, além da exigência da condenação dos acusados, colocandose em xeque a reputação dos Ministros em caso de decisão em sentido oposto. No mesmo sentido, a sociedade em geral deixava clara sua predileção pela condenação dos acusados, o que foi confirmado através de pesquisa do "Instituto Datafolha", onde $83 \%$ dos entrevistados afirmavam conhecer o caso, e que $74 \%$ deles exigiam a prisão imediata dos acusados/condenados. (ARAÚJO, 2013, p. 77)

Ao fim das investigações, a Procuradoria-Geral da República, acabou por denunciar quarenta pessoas das quais, apenas seis, possuíam foro perante o STF. Até o início do caso "mensalão", o entendimento do Supremo quanto a essa situação era de que deveriam ser processados e julgados no Tribunal apenas os detentores do foro por prerrogativa, devendo os demais acusados serem demandados nas instâncias inferiores. (LOPES JR, 2018)

Não obstante, havia pressão da opinião pública não só pela punição dos envolvidos, 
mas também que o STF julgasse a totalidade dos acusados (O GLOBO, 2012). Sobre o fato, destacou o Min. Alexandre de Morais que a sociedade brasileira clamava ao Supremo que não desmembrasse o processo, sob pena de ocorrência de impunidade, mostrando uma confiança popular na capacidade da Suprema corte de combate à corrupção. A mesma versão foi endossada pelo Min. Dias Toffoli, para o qual, à época, havia a sensação que o caso jamais seria julgado senão pela atuação do Supremo Tribunal Federal. (STF, AP 937)

Ainda que o art. 80 do Código de Processo Penal permitisse a prática do desmembramento dos autos por excesso de acusados, parte dos Ministros do Supremo concluiu que essa manobra traria prejuízos para o entendimento do caso. Nesse sentido, com o desmembramento, o mesmo caso seria julgado por vários juízos diferentes, o que poderia gerar uma série de decisões contraditórias para um mesmo fato, (PACELLI, 2018, p. 194) gerando insegurança jurídica e um risco de descrédito do Judiciário.

Nos votos dos Ministros, a preocupação com os anseios sociais é percebida no teor das decisões favoráveis ao não desmembramento do Inquérito e, por conseguinte, pela extensão do foro por prerrogativa aos acusados que não a detinham. Destaca-se, nesse ponto, a Min. Cármen Lúcia, que em seu voto afirmou que a sociedade esperava uma resposta jurídica conveniente, acertada e célere, e somente uma jurisdição diferenciada por parte do STF seria capaz de dar a devida resolução àquele caso. A posição da Min. Cármen Lúcia também foi adotada pelo Min. Celso de Mello. (STF, ADI 2245)

O Min. Eros Grau, por sua vez, afirmou que o caso "mensalão" seria citado em anos posteriores quando se tratasse da história do próprio Tribunal e, portanto, a Corte deveria aceitar o desafio e o excesso de trabalho e julgar todo o grupo de pessoas acusadas. Por fim, a então Presidente do STF, Min. Ellen Gracie, por sua vez, afirmou que a Corte estava capacitada e apta para julgar qualquer causa, enquanto o Min. Gilmar Mendes, deixou claro que o caso "mensalão" só estava chegando ao seu final por ter permanecido e concentrado sob a jurisdição do STF. (ARANTES, 2018, p. 355)

Ao final, a maioria da Corte, apoiada nesses e em outros argumentos, decidiu pela competência do STF para julgamento de todos os acusados a evitar prejuízos no julgamento por possíveis contradições quanto ao julgamento do mesmo fato por juízos diferentes. Todavia, o que teria levado a Corte a superar seus precedentes para impor nova posição a 
julgar acusados com e sem foro perante o Tribunal, expandindo a aplicação do instituto? Em análise inicial, sugere-se a opinião pública como fator explicativo dessa reviravolta jurisprudencial.

O atendimento à opinião pública pode trazer ao Tribunal um ganho de poder político. No caso em tela, em ocorrendo o desmembramento dos autos, ter-se-ia o quadro de grande deslocamento de processos que estavam sob a jurisdição do STF para outras instâncias judiciais. Na prática, esse movimento implicaria na renúncia ao poder de resolver um dos mais emblemáticos casos de corrupção da história da República. Ao manter o foro dos acusados sob sua jurisdição, o Supremo assumiu o protagonismo do caso, podendo aumentar e impor sua liderança institucional perante todo o Judiciário ao se mostrar capaz de impor decisões. (ARANTES, 2018, p. 343-344)

No mesmo sentido, Gretchen Helmke (2010, p. 397) aduz que o poder judicial aumenta quando juízes são capazes de entender um contexto formado pelo que denomina de "humor público", coincidindo suas decisões a esse cenário. À medida que um Tribunal consegue obter o apoio público em suas manifestações, cresce também seu poder político capaz de resistir a eventuais ataques à sua autoridade e função jurisdicional. Desta maneira, a opinião pública se mostra como importante instrumento a aumentar a capacidade da Corte no combate à corrupção, realizar melhoras nas condições democráticas do país, podendo resistir a potenciais ameaças de represálias ou de não cumprimento de suas decisões. (LUNARDI, 2020, p. 250)

Para André Rufino do Vale (2015, p. 326-327), é plausível a afirmação de que em casos mais polêmicos, o Supremo Tribunal Federal se mostra como uma "caixa de ressonância da opinião pública expressada por diversos canais legítimos”. Por conseguinte, é possível que a pressão da sociedade pela punição dos envolvidos no caso "mensalão" pode ter contribuído decisivamente para que o STF monopolizasse seu julgamento, garantindo, ainda que por alto custo, que os acusados de fato seriam julgados. (STF, 2021)

Todavia, se a opinião pública, em certa medida, influenciou o STF a promover a expansão das regras do foro por prerrogativa, ela também pode, quase uma década depois, promover um movimento oposto no modelo decisório da Corte sobre o foro por prerrogativa. Essa alteração jurisprudencial ocorreu, quando do julgamento de Questão de Ordem na Ação 
Penal n. ${ }^{\circ}$ 937/RJ entre os anos de 2017 e 2018.

No caso em questão, por iniciativa do Relator do caso, Min. Luís Roberto Barroso, foi proposta uma reinterpretação do art. 102, I, “b”, da Carta Magna de 1988, consistindo em uma restrição na aplicação das regras do foro por prerrogativa. Pela nova orientação, o Supremo Tribunal Federal seria competente a julgar apenas os crimes relacionados ao tempo e ao exercício do cargo ocupado por parlamentares. Os demais delitos, como o caso tratado na Ação Penal n. ${ }^{\circ}$ 937-RJ, que não possuíssem relação com a função desempenhada, deveriam ser julgados pelas instâncias iniciais. (STF, AP 937)

Para entender os motivos que levaram o STF a rever sua posição e caminhar em sentido contrário ao anterior, se faz necessário entender o contexto político e social que o país atravessava naquele momento, tendo em vista um potencial influência no processo decisório do presente caso.

A partir do ano de 2014, uma sucessão de investigações e operações policiais acabaria por fazer explodir o número de ações contra políticos de todas as esferas e cargos na Administração Pública. A denominada “Operação Lava-jato" consistiu em ações conjuntas que envolveram a Polícia Federal, o Ministério Público Federal, diversos órgãos de controle em uma investigação que descobriu um complexo esquema de fraudes em contratos que envolviam agentes políticos, empreiteiras e a Empresa Estatal Petróleo do Brasil S.A. PETROBRÁS.

As ações penais em desfavor das pessoas comuns transcorreram na $13^{\text {a }}$ Vara Federal de Curitiba-PR, cujos trabalhos ficaram marcados pela celeridade processual. Segundo matéria jornalística da época, nos quatro primeiros anos de operação, a referida Vara proferiu 188 (cento e oitenta e oito condenações) em 40 (quarenta) processos, cujo tempo médio de tramitação foi de 9 (nove) meses e 10 (dez) dias (PAVANELLI, 2021). Ainda que a Vara fosse especializada na matéria, e contasse com o apoio da Corregedoria do Tribunal Regional Federal da $4^{\mathrm{a}}$ Região para o desenvolvimento dos trabalhos (MPF, 201?), a celeridade na prestação jurisdicional foi tamanha que elevou o juiz do caso, à época, ao status de "herói nacional". (NETTO, 2016, p. 125)

Enquanto isso, efeitos da citada operação batiam às portas do Supremo Tribunal Federal, resultando em considerável número de abertura de inquéritos e ações penais em 
desfavor de autoridades que possuíam foro penal na Corte. Todavia, ainda que se contabilizasse um vultuoso número de 11 (onze) mil decisões proferidas no caso, diferentemente da instância inicial, os trabalhos no Supremo não demonstraram a mesma agilidade quando ao julgamento de mérito se comparados à primeira instância. Segundo o próprio Tribunal, em balanço publicado em setembro de 2020, a Corte que chegou a contar em seu acervo 125 (cento e vinte e cinco) ações penais referentes à "lava-jato", registrava à época apenas 5 (cinco) decisões de mérito, com uma condenação em execução, uma absolvição e 3 (três) condenações em fases recursais. (STF, 2020)

A complementar o cenário em questão, durante o julgamento da Ação Penal n. ${ }^{\circ} 937$ RJ, foi divulgada pesquisa de opinião a qual revelou uma repulsa social ao foro por prerrogativa. Dos entrevistados, 78\% afirmaram que essa prerrogativa deveria acabar, enquanto $77 \%$ apontaram que o fim do instituto auxiliaria no combate à corrupção. Finalmente, quanto ao nível de confiança no STF, 36\% dos entrevistados disseram que ele aumentaria caso a Corte decidisse pela "extinção" do foro, enquanto 45\% afirmaram que o índice seria mantido caso ocorresse a hipótese levantada. (G1, 2018)

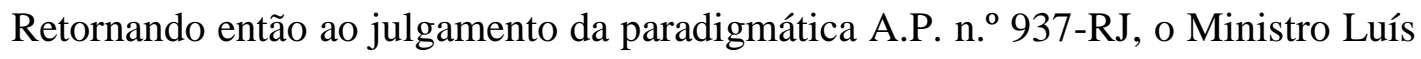
Roberto Barroso, justificou em sua proposta que o foro por prerrogativa no STF era causa de indignação à sociedade e de desprestígio ao Tribunal. Dessa forma, o Min. Barroso defendeu que o dispositivo Constitucional que trata da matéria deveria ser interpretado restritivamente, sob os princípios da igualdade e da República. Finalmente, o Relator defendeu sua proposta ao afirmar ser possível "interpretar a Constituição de modo a atender os anseios da sociedade, se isso for compatível, e sobretudo se esta for a interpretação mais adequada da Constituição”. (STF, A.P. 937)

A consideração da opinião pública quanto ao foro por prerrogativa, manifestada pelo Relator, também foi acompanhada pelos outros Ministros que seguiram a proposta de reinterpretação do instituto. A Ministra Rosa Weber afirmou estarem presentes hipóteses de mutação constitucional por uma "mudança de realidade fática, seja pela mudança na percepção de qual seja a melhor exegese, seja pelas consequências práticas da orientação dominante, geradoras de impunidade e mesmo de desprestígio ao Judiciário".

No mesmo sentido, o Ministro Luiz Fux afirmou ser "latente o sentimento social que 
relaciona, com razão, a interpretação ampliativa das hipóteses de cabimento da competência especial por prerrogativa de função à impunidade”. Finalmente, o Min. Celso de Mello, assistindo razão à proposta trazida pelo Relator, afirmou que a reinterpretação restritiva do foro traduziria uma reação do STF “a um modelo que efetivamente tem comprometido a funcionalidade e a regularidade do exercício da jurisdição penal” da Corte.

Dessa forma, o Tribunal, por sete votos a quatro, acolheu a tese proposta do Min. Luís Roberto Barroso para reinterpretação do foro por prerrogativa de forma mais restritiva, limitando-se a competência do STF para julgar crimes praticados em razão da função e durante seu exercício. Desses votos, a preocupação com a opinião pública foi percebida, explicitamente, nos votos de cinco dos sete Ministros que compuseram a proposta vencedora, se apresentando, mais uma vez, como um dos elementos formadores da aplicação do foro por prerrogativa

\subsection{O TEMOR PELA PRESCRIÇÃO COMO FUNDAMENTO DECISÓRIO}

Há um elemento de caráter jurídico, mas de reflexos direto na opinião pública, que também se apresenta como um fator decisório nas posições adotadas pelo Supremo, explicativo quanto ao estabelecimento de parâmetros interpretativos, e a fundamentar viradas jurisprudenciais. Esse elemento é a prescrição, por vezes surgindo como um "fantasma" que assombra o STF quando o assunto é sua competência penal originária, tendo em vista que ela é mormente apontada como responsável pela impunidade de altas autoridades. Suas consequencias são capazes de minar a reputação, causar grita e gerar descontentamento popular em relação a um Tribunal Constitucional. (REALE, 2017)

A ocorrência da prescrição no Supremo Tribunal Federal não se apresenta exatamente como um acaso, mas um fenômeno atestado por números. Segundo estudo publicado pela Associação dos Magistrados Brasileiros, denominado "Juízes contra a corrupção", demonstrou-se que entre o ano 2000 até 2007, foram extintas no STF um total de 13 (treze) ações penais em razão da prescrição, o que corresponde a 10\% (dez por cento) do total de ações da espécie que tramitaram no Tribunal nesse período (AMB, 2007). Já levantamento feito pelo jornal "Folha de São Paulo", aponta que entre 2007 e 2016, um terço das ações penais em desfavor de parlamentares foram extintas em decorrência da prescrição 
(FOLHA, 2016). E em voto na Ação Penal n. o 937-RJ, o Ministro Luís Roberto Barroso expôs dados da Assessoria de Gestão Estratégica do Tribunal, os quais apontavam que cerca de 200 ações prescreveram desde que a Corte passou a atuar nessa matéria. Por essa razão, o Min. Barroso sobre o foro no Supremo, assim concluiu: "o sistema é ruim; o sistema funciona mau; o sistema traz desprestígio para o Supremo; o sistema traz impunidade". (STF, AP 937)

Tamanha ocorrência de casos de prescrição geram na sociedade um sentimento de descrédito, além da perda de legitimidade do Judiciário enquanto poder. (VAZ, 2010) E essa perda de legitimidade social implica, diretamente, na diminuição de capital político da Corte, elemento este essencial para a tomada de decisões contrárias aos interesses de elites políticas como no julgamento de parlamentares com foro por prerrogativa. Dessa forma, percebe-se porque a prescrição é um fenômeno tão indesejado pelo Supremo. (LUNARDI, 2020, p. 6869)

Pelas razões apresentadas, a prescrição tornou-se o fator a explicar o porquê o Tribunal proferiu decisões diferentes em casos de circunstâncias muito semelhantes, e que envolviam o foro por prerrogativa: trata-se do julgamento, em 2007, da Ação Penal n. ${ }^{\text {o } 333-}$

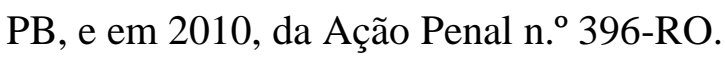

No julgamento da A.P. n. ${ }^{\text {o } 333-P B, ~ s o b ~ r e l a t o r i a ~ d o ~ M i n . ~ J o a q u i m ~ B a r b o s a, ~ o ~}$ Supremo Tribunal Federal se deparou com Questão de Ordem a legalidade, ou não da renúncia do acusado, Deputado Federal, às vésperas do julgamento na Corte. A renúncia do acusado acarretaria na perda do cargo público, e no consequente deslocamento da competência do STF e do processo para primeira instância. O Relator, então, pugnou pela tese que a renúncia representaria abuso de direito se o caso já estivesse pautado para julgamento, sob pena de uma "chicana processual", face os atendados a princípios como boafé, moralidade e supremacia do interesse público sobre o particular. (STF, AP 333)

Ainda que a decisão do caso girasse, juridicamente, em torno da avaliação da renúncia como direito subjetivo ou abuso de direito, o tema da prescrição acabou se mostrando como fator presente na tomada de decisão de alguns Ministros. Segundo o Relator, o caso já tramitava sem resolução há quatorze anos, sendo que o acusado que já possuía mais setenta anos de idade. Dessa forma, o aproximar da prescrição era uma 
realidade que não deveria ser desprezada pelos Ministros.

Sobre esse ponto, o Min. Cezar Peluso argumentou que toda a fase instrutória do processo ocorreu, durante dez anos, sob competência do Supremo Tribunal Federal, resultando em autos com mais de cem volumes. A remessa de um processo de tamanho proporcional à sua complexidade ao juízo de primeiro grau, traria duplo prejuízo: ao STF, que teria demandado esforços em vão ao instruir os autos para posteriormente não julgá-lo; e o iminente risco de prescrição, tendo em vista que o tempo que juízo de primeira instância levaria para estudar e se situar diante das circunstâncias dos autos, seria o suficiente para que cessasse o ius puniedi estatal. Na mesma esteira de Peluso, seguiu a Ministra Cármen Lúcia. (STF, AP 333)

Todavia, a tese vencedora foi a divergência apresentada pelo Min. Marco Aurélio ao considerar a renúncia do congressista como ato legítimo, capaz de transformar o acusado de parlamentar em cidadão comum, e não passível de questionamento. A consequência natural, portanto, era a cessação da competência penal do Supremo, devendo-se declinar os autos ao juízo de primeira instância. As razões foram acompanhadas pelos Ministros Eros Grau, Menezes Direito, Gilmar Mendes, Celso de Mello e Elen Gracie, que não citaram a prescrição como fundamento de seus votos.

Todavia, três anos depois, o Supremo se viu diante de situação praticamente idêntica, quando do julgamento da Questão de Ordem na Ação Penal n. ${ }^{\circ}$ 396-RO. Em resumo, novamente um parlamentar renunciava ao cargo às vésperas do julgamento pelo Plenário da Corte, o que provocaria o deslocamento da competência da Suprema Corte para a instância inicial. Todavia, se na A.P. n. ${ }^{\text {o } 333-P B ~ o ~ e l e m e n t o ~ p r e s c r i c ̧ a ̃ o ~ f e z-s e ~ p r e s e n t e, ~ p o r e ́ m ~ n a ̃ o ~}$ decisivo no resultado do juízo da Corte, na A.P. n. ' 396-RO, ele se apresentou como condição preponderante para o resultado do julgamento, sem desprezo de outros argumentos técnicos jurídicos citados pelos Ministros.

A Relatora do caso, Min. Cármen Lúcia, destacou que o crime a ser julgado foi praticado em 1999, cuja ação penal tramitou em vários órgãos do Judiciário até chegar ao STF, o que aconteceu quando o acusado foi eleito Deputado Federal. Após a Corte Constitucional promover uma longa instrução processual, no dia anterior à data do julgamento em Plenário, o acusado renunciou ao mandato sendo que, exatamente, oito dias 
depois, o crime seria alcançado pela prescrição. Assim, destacou a Relatora que caso houvesse o deslocamento dos autos para a instância inicial, a pretensão punitiva do Estado seria extinta, ocasionando situação de impunidade deliberada.

Por sua vez, o Min. Dias Toffoli afirmou que o acusado renunciara ao cargo para, exclusivamente, se furtar à ação penal. Não obstante, o Ministro ainda defendeu a Suprema Corte diante de acusação de suposta ineficiência quanto ao foro por prerrogativa, lembrando que vários congressistas vinham renunciando aos cargos visando a remessa dos autos do STF para as instâncias iniciais. O objetivo seria, a partir daí, efetuar o maior manejo de recursos possíveis a alongar a marcha processual para, ao final, buscar a prescrição do crime ou da execução da pena.

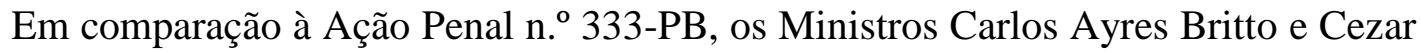
Peluso mantiveram suas posições, votando pela manutenção da competência do STF para julgar os congressistas renunciantes, seja pela caracterização de intenção de provocar fraude à lei, bem como evitar-se a prescrição do caso. Já os Ministros Ricardo Lewandowski, Gilmar Mendes, Ellen Gracie, revisaram suas posições em relação à Ação Penal n. ${ }^{\circ}$ 333, filiando-se à tese proposta pela Relatora, a evitar que a manobra realizada pelo acusado causasse a prescrição punitiva dos crimes praticados. O único voto divergente foi proferido pelo Min. Marco Aurélio, que também mantendo posicionamento anterior, não vislumbrou a renúncia como abuso de direito, afirmando que a saída do cargo cessaria o foro por prerrogativa no STF.

Por fim, por oito votos a um, o Supremo Tribunal Federal decidiu que a renúncia do parlamentar ao mandato, às vésperas de seu julgamento pelo Plenário da Corte, visando efeitos como a prescrição, constituir-se-ia abuso de direito. Com efeito, a renúncia não serviria como meio a impedir do julgamento pela Corte, "o que ensejou a perpetuação da jurisdição da Suprema Corte. Decisão absolutamente correta, e que, de resto, prestigia o regular exercício do voto popular” (PACELLI, 2020, p. 191-192). Assim, novamente o STF definiu, via jurisprudência, mais uma regra processual a fazer parte da ciranda jurisprudencial do foro por prerrogativa.

Na comparação das decisões na Ação Penal n. ${ }^{\circ}$ 333-PB e Ação Penal n. ${ }^{\circ}$ 396-RO, vislumbra-se que o elemento prescrição se mostrou como o elemento para a definição da 
abdicação do mandato parlamentar como fraude ou não. Ademais, a própria efetividade da jurisdição criminal no STF foi garantida.

Destaca-se que o receio da prescrição, e do desgaste que a Suprema Corte pode herdar com sua ocorrência, também pode ser verificado em outros julgamentos do Tribunal, como é o caso do Inquérito n. ${ }^{\circ}$ 2.245-DF, tratado no item anterior. Naquele caso, a discussão sobre o desmembramento dos autos ou não, passou não só por argumentos como a possibilidade de decisões contraditórias e a capacidade da Corte em efetuar o julgamento, mas também pela possibilidade de prescrição. Dos onze Ministros, oito externaram preocupação com a possibilidade de prescrição do caso, o que ao final levou o Tribunal não só a manter o caso sob sua competência, bem como proceder os devidos esforços para o julgamento do caso em tempo hábil a apresentação de uma resposta à sociedade.

\section{CONSIDERAÇÕES FINAIS}

Por todo exposto, o presente artigo pretendeu em sua essência, analisar o foro por prerrogativa no Supremo Tribunal Federal sob dois ângulos de observação: sua evolução na jurisprudência da Corte, e exame empírico das principais razões decisórias. Em um cenário de escassez de novas positivadas sobre o tema, entender como o STF promove essas modificações em seus precedentes sobre o tema, investigando quais fatores endógenos e exógenos são utilizados pelos membros da Corte, foi o objetivo do artigo.

Das leitura dos votos dos Ministros, fica evidente a presença dos principais elementos identificadores como propulsores das decisões do Supremo, sejam eles a política, a opinião pública e a iminência da prescrição, sem desprezar a existência de outros. Contudo, de todos os fatores observáveis, o fator politica é aquele observável de forma mais nítida entre todos, o que de certa forma se mostra natural pela natureza politica que detém a Corte Constitucional.

Invocando princípios como a igualdade republicana, excesso de processos, e proteção ao exercício do cargo público e não ao seu ocupante, o Supremo promoveu duas grandes restrições ao foro por prerrogativas com fundamentos políticos: em 1999, quando do

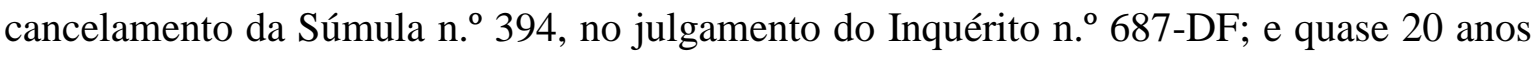
depois e na A.P. n. ${ }^{\circ}$ 937-RJ. Em comum, além dos fundamentos e consequências da decisão, 
afirma-se que tratam-se de decisões que buscavam promover uma agilidade dos trabalhos da Corte, afastando a imagem de Tribunal lento e obsolete. A consequência é a obtenção de capital politico junto à sociedade, já que demonstrações de celeridade nos trabalhos geram importante e positive repercussão social.

Todavia, a política também pode gerar decisões criticáveis e inexplicáveis, como as diferentes decisões proferidas em casos similares, como no julgamento das ADI 3.289-DF e ADI 2.797-DF. Nesses casos, torna-se impossível, do ponto de vista jurídico, justificar o motivo de decisões dispares. Se esses casos evidenciam como a política faz o Tribunal movimentar sua jurisprudência, por outro levantam suspeitas de prática de constitucionalismo abusivo e seletivo.

De todos esses elementos, a opinião ainda que veladamente, também se mostra como forte elemento decisório dentro do Tribunal, tendo em vista que não foram raros os votos onde Ministros admitiram que o clamor social se encontrava dentro das razões da tomada de decisão. Nesse sentido, ressalta-se que Tribunal tem manejado com competência esse fator de influência externa, atendendo na correta medida os reclames populares sem ao mesmo tempo, se deixar comandar por comoções.

A pesquisa, então, permite concluir que o foro por prerrogativa não é a causa das mazelas do país, como afirmou o Min. Gilmar Mendes em um debate na Corte durante o julgamento da A.P. n. ${ }^{\circ}$ 937. Instrumento de grande importância na proteção à liberdade no exercício das altas funções da República, o foro por muitos anos evitou que demandas frívolas fossem propostas como meio de perseguições políticas, utilizando-se do Poder Judiciário como instrumento a este fim.

Diante desse cenário, o Supremo buscou, entre erros e acertos, aprimorar seu papel como órgão instrutório penal, a garantia um efetivo julgamento às autoridades sob sua jurisdição. A limitação em realizar mudanças e criar de balizas, diante de uma ausência de regras, representou um desafio à Corte a buscar um processo racional, e até mesmo moral, a garantir a eficiência de sua atuação e atender demanda social de combate à corrupção. E, de alguma maneira, o girar da ciranda jurisprudencial representou a busca do Tribunal, ainda que lentamente, por um foro por prerrogativa condizente com a maturidade de um país recém democratizado, evoluindo de uma herança aristocrática rumo ao republicanismo. 


\section{REFERÊNCIAS}

ABBOUD, Georges. Processo Constitucional Brasileiro. 2. ed. São Paulo: Thomson Reuters Brasil, 2018.

ARANTES, Rogério. Mensalão: um crime sem autor. In: MARINA, Marjorie Corrêa; DEL RÍO, Andrés (Org.). Justiça no Brasil: às margens da democracia. Belo Horizonte: Arraes, 2018, p. 338-389.

ARAUJO, Mateus Morais. Comportamento estratégico do Supremo Tribunal Federal. 2017. 106 f. Tese (Doutorado em Ciência Política). Faculdade de Filosofia e Ciências Sociais, Universidade Federal de Minas Gerais, Belo Horizonte, 2017.

Aristóteles. Política. Coleção a obra-prima de cada autor. v. 61. São Paulo: Martin Claret, 2006.

ASSOCIAÇÃO DOS MAGISTRADOS BRASILEIROS (AMB). Juízes contra a corrupção: o fim do foro privilegiado. Estudo. Brasília: AMB, 2007, 44 p. Disponível em: <https://www.oas.org/juridico/PDFs/mesicic4_bra_stf.pdf>. Acesso em: 30. Set. 2020.

BARROSO, Luis Roberto. Curso de Direito Constitucional contemporâneo. 7. ed. São Paulo: Saraiva, 2018.

BERCOVICI, Gilberto. Constituição e política: uma relação difícil. Lua Nova, n. 61, p. 524, 2004. ISSN 1807-0175. Disponível em: <https://doi.org/10.1590/S010264452004000100002>. Acesso em: 13 abr. 2021.

BENVINDO, Juliano Zaiden. O Supremo Tribunal Federal como agente do constitucionalismo abusivo. Cadernos Adenauer XVIII, Rio de Janeiro, nº 1, p. 173-192, jul. 2017.

BOBBIO, Norberto. Dicionário de Política. 11. ed. v. 1. Brasília: Universidade de Brasília, 1998.

CANOTILHO, José Joaquim Gomes; MENDES, Gilmar Ferreira. Comentários à Constituição do Brasil. 2. ed. São Paulo: Saraiva, 2018.

DATAFOLHA. Maioria quer réus do mensalão presos, mas prevê absolvição. Datafolha: Instituto de pesquisa. São Paulo, 08. ago. 2012, Opinião Pública. Disponível em: $<$ https://datafolha.folha.uol.com.br/opiniaopublica/2012/08/1204844-maioria-quer-reusdo-mensalao-presos-mas-preve-absolvicao.shtml.>. Acesso em: 12 mai. 2021.

DO VALE, André Rufino. Argumentação Constitucional: um estudo sobre a deliberação nos Tribunais Constitucionais. 2015, 415 f. Tese (Doutorado em Direito) - Universidade de Brasília, Universidade do Alicante; Brasília, 2015. Disponível em: 
<https://repositorio.unb.br/handle/10482/18043>. Acesso em: 19 out. 2020.

FALCÃO, Joaquim. O Supremo. 2. ed. Rio de Janeiro: Edições de Janeiro, 2015.

FOLHA DE SÃO PAULO. Um terço das ações contra políticos no STF prescreve. Congresso em foco. Brasília, 14. Nov. 2016. Disponível em: $<$ https://congressoemfoco.uol.com.br/especial/noticias/um-terco-das-acoes-contrapoliticos-no-stf-prescreve/> . Acesso em: 14 mai. 2021.

G1. Pesquisa IBOPE aponta que 78\% dos entrevistados defendem o fim do foro privilegiado. G1, Política, 02. Mai. 2018, Brasília. Disponível em: <https://g1.globo.com/politica/noticia/pesquisa-ibope-aponta-que-78-dos-entrevistadosdefendem-o-fim-do-foro-privilegiado.ghtml>. Acesso em: 20 mai. 2021.

HÄBERLE, Peter. A Jurisdição Constitucional na Fase Atual de Desenvolvimento do Estado Constitucional. Revista de Direito Administrativo. Rio de Janeiro, v. 244, p. 208-230, jan. 2007. ISSN 2238-5177. Disponível em: <http://bibliotecadigital.fgv.br/ojs/index.php/rda/article/view/42470>. Acesso em: 02 set. 2020.

HELMKE, Gretchen. Public Support and Judicial Crises in Latin America. Journal of Constitution Law, v. 13, n. 2, p. 397-411, 2010. Disponível em: <https://scholarship.law.upenn.edu/jcl/vol13/iss2/7>. Acesso em: 17 mai. 2021.

HESSE, Konrad. Temas fundamentais do Direito Constitucional. Série IDP. São Paulo: Saraiva, 2009.

LANDAU, David. Abusive Constitutionalism. U.C. Davis Law Review, University Of California, v. 47, n. 1, p. 189-260, nov. 2013.

LOPES JR, Aury. Direito processual penal. 15. ed. São Paulo: Saraiva, 2018.

LUNARDI, Fabrício Castagna. O STF na política e a política no STF. São Paulo: Saraiva, 2020.

MARINONI, Luis Guilherme. A ética dos precedentes. 9. ed. São Paulo: Thomson Reuters Brasil, 2019.

MARQUES, Ângela Cristina Salgueiro; SÁ MARTINO, Luis Mauro. O conceito de opinião pública na teoria da comunicação: genealogias e modos de abordagem. Revista Brasileira de Comunicação Organizacional e Relações Públicas. Departamento de Relações públicas, Propaganda e Turismo, Escola de Comunicações e Artes, Universidade de São Paulo. v. 1, n. 1. São Paulo: ECA-USP/Gestcorp, 2004.

MARCHIONATTI, Daniel. Processo Penal contra autoridades. Rio de Janeiro: Forense, 2019. 
MELlO, Patrícia Perrone Campos. Nos bastidores do Supremo Tribunal Federal: constituição, emoção, estratégia e espetáculo. 470f. Tese (Doutorado). Universidade do Estado do Rio de Janeiro, Faculdade de Direito, 2014.

MINISTÉRIO PÚBLICO FEDERAL. Site do Ministério Público Federal. Caso lava-jato: Entenda o caso. Disponível em: <http://www.mpf.mp.br/grandes-casos/lava-jato/entenda-ocaso $\geq$. Acesso em: 25 abr. 2020.

NETTO, Vladimir. Lava jato: o juiz Sérgio Moro e os bastidores da operação que abalou o Brasil. Rio de Janeiro: Primeira Pessoa, 2016.

O GLOBO. Afronta ao Supremo e ao estado de direito. In: O Globo. Opinião. Rio de Janeiro, 04.out. 2012. Disponível em: <https://acervo.oglobo.globo.com/consulta-aoacervo/?navegacaoPorData=201020121004>. Acesso em: 19 mai. 2021.

OLIVEIRA, Eugênio Pacelli de. Comentários ao Código de Processo Penal e sua jurisprudência. 12. ed. São Paulo: Saraiva, 2020.

REALE JÚNIOR, Miguel. Foro privilegiado? O Estado de São Paulo. São Paulo, 07 de jan. 2017. Disponível em: <https://opiniao.estadao.com.br/noticias/geral,foroprivilegiado,10000098670>. Acesso em: 12 jan. 2019.

STF, Tribunal Pleno. Ação Direta de Inconstitucionalidade no 2.587 (GO). Rel. Min. Maurício Corrêa. j. 01.12.2004. DJ. 06.11.2006.

STF, Tribunal Pleno. Ação Direta de Inconstitucionalidade no 2.797 (DF). Rel. Min. Sepúlveda Pertence. j. 15.09.2005. DJ. 19.12.2006.

STF, Tribunal Pleno. Ação direta de inconstitucionalidade no 3.289 (DF). Tribunal Pleno. Rel. Min. Gilmar Mendes. j. 05.05.2005. DJ. 24.02.2006.

STF, Tribunal Pleno. Ação Penal no 333-PB (Q.O.). Rel. Min. Joaquim Barbosa. j. 05.12.2007. DJ. 11.04.2008.

STF, Tribunal Pleno. Ação Penal no 396-RO (Q.O.). Rel. Min. Cármen Lúcia. j. 28.10.2010. DJ. 28.04.2011.

STF, Tribunal Pleno. Ação Penal no 536-MG (Q.O.). Rel. Min. Luís Roberto Barroso. j. 27.03.2014. DJ. 12.08.2014.

STF, Tribunal Pleno. Ação Penal no 937-RJ (Q.O.). Tribunal Pleno. Rel. Min. Luís Roberto Barroso. j. 03.05.2018. DJ. 11.12.2018.

STF, Tribunal Pleno. Lava jato: Relator já proferiu mais de 11 mil decisões e despachos no curso da operação. Supremo Tribunal Federal, Imprensa, 11. Set. 2020, Brasília. Disponível em: 
<http://portal.stf.jus.br/noticias/verNoticiaDetalhe.asp?idConteudo=451566\&ori=1>. Acesso em: 19. Mai. 2021.

STF, Tribunal Pleno. Inquérito no 687-SP (Q.O.). Rel. Min. Sydney Sanches. j. 25.08.1999. DJ. 09.11.2001.

STF, Tribunal Pleno. Inquérito no 2.245-MG. (Q.O). Rel. Min. Joaquim Barbosa. j. 28.08.2007. DJ. 09.11.2007.

STF, Tribunal Pleno. Reclamação no 25.537 (DF). Rel. Min. Edson Fachin. j. 26.06.2019. DJ. 11.03.2020.

PAVANELI, Aline. Lava jato completa quatro anos com 40 sentenças de Sérgio Moro; tempo médio de tramite das ações é de 9 meses. G1 PR. 17 mar. 2018, Curitiba, Paraná. Disponível em: <https://g1.globo.com/pr/parana/noticia/lava-jato-completa-quatro-anoscom-40-sentencas-de-sergio-moro-tempo-medio-de-tramite-das-acoes-foi-de-novemeses.ghtml>. Acesso em: 19 mai. 2021.

TOURINHO FILHO, Fernando da Costa. Da competência pela prerrogativa de função. Coleção Doutrinas essenciais: Direito Penal, ano. 1, v. 1. São Paulo: Revista dos Tribunais, 2012.

Data da submissão: 27/08/2021

Data da primeira avaliação: 30/08/2021

Data da segunda avaliação: 16/10/2021

Data da aprovação: 16/10/2021 